\title{
PENINGKATAN HASIL BELAJAR SISWA MELALUI PENERAPAN MODEL PEMBELAJARAN DISCOVERY LEARNING
}

\author{
Rihwan Suhada $^{1 *}$, Irdam Idrus ${ }^{1}$, dan Kasrina ${ }^{1}$ \\ ${ }^{1}$ Program Studi Pendidikan Biologi, Fakultas Keguruan dan Ilmu Pendidikan, Universitas Bengkulu \\ Email : rihwanbio14@gmail.com
}

\begin{abstract}
Abstrak
Penelitian ini bertujuan untuk mendeskripsikan aktivitas mengajar guru, aktivitas belajar siswa dan hasil belajar siswa di kelas VIII ${ }_{\mathrm{A}}$ Sekolah Menengah Pertama (SMP) Negeri 26 Seluma melalui model Discovery Learning. Jenis penelitian ini termasuk dalam penelitian tindakan kelas dengan metode deskriptif. Penelitian ini terdiri dari dua siklus, dan setiap siklus terdiri atas empat tahap yaitu perencanaan, pelaksanaan, observasi, dan refleksi. Subyek penelitian ini adalah guru biologi dan siswa kelas VIII S SMP Negeri 26 Seluma tahun ajaran 2017/2018 yang berjumlah 20 orang. Instrumen yang digunakan berupa lembar observasi dan lembar tes. Teknik analisis data yang digunakan yaitu rerata dan kategori skor. Hasil penelitian menunjukkan bahwa rerata aktivitas guru dan siswa pada siklus I sebesar 24 (baik) dan pada siklus II meningkat menjadi 26 (baik). Hasil belajar kognitif siswa pada siklus I dengan persentase ketuntasan klasikal 65\% (belum tuntas) dan pada siklus II meningkat dengan persentase ketuntasan klasikal $85 \%$ (tuntas). Kesimpulan dari hasil penelitian ini adalah penerapan model Discovery Learning dapat meningkatkan aktivitas dan hasil belajar siswa di kelas $\mathrm{VIII}_{\mathrm{A}} \mathrm{SMP}$ Negeri 26 Seluma pada materi fotosintesis.
\end{abstract}

Kata kunci: Discovery Learning, aktivitas guru dan siswa, hasil belajar

\begin{abstract}
This research aims to describe the learning activity of teacher and students, and learning outcomes of the students in VIIIA class, State Senior High School (SMPN) 26 Seluma by using Discovery Learning model. This research is a classroom action research with qualitative-descriptive as a method. The research consists of two cycles with each cycle was divided into four phases: planning, implementation, observation, and reflection. The subject of this research was teacher and students at class VIIIA SMPN 26 Seluma, academic year 2017/2018. The used instruments in this research were the observation and test sheets. The data was analyzed descriptively by calculating the average of the scores, and the be categorized. The results of this research showed that the average score of teacher and students learning activities in the first cycle is 24 (good), and increased to 26 (good) in the cycle II. The learning outcomes of the students in cycle I was $65 \%$ (incomplete) and improved in cycle II to $85 \%$ (complete). The conclusion of this research is an application of Discovery Learning model at VIIIA SMP Negeri 26 Seluma can improve the learning activity of the teacher and student, and learning outcomes of the students.
\end{abstract}

Keywords: Discovery Learning, teacher and student activity, learning outcomes 


\section{PENDAHULUAN}

Perkembangan ilmu pengetahuan dan teknologi yang pesat di era global sekarang ini menuntut individu untuk berkembang menjadi manusia berkualitas yang memiliki pemikiran kreatif dalam menjawab segala tantangan dan permasalahan yang ada. Pendidikan sangat berperan dan merupakan faktor utama dalam pembentukan pribadi manusia. Pendidikan harus berwawasan masa depan yang memberikan jaminan bagi perwujudan hak-hak asasi manusia untuk mengembangkan seluruh potensi dan prestasinya secara optimal guna kesejahteraan hidup di masa depan (Kemendikbud, 2013).

$\begin{array}{lcc}\text { Pembentukan generasi penerus } & \text { perkualitas dan mampu } \\ \text { yang ben diri untuk hidup }\end{array}$ menyesuaikan diri untuk hidup bermasyarakat, berbangsa dan bernegara, membutuhkan sistem pendidikan yang baik dan berkualitas. Pendidikan yang berkualitas dapat dicapai melalui beberapa proses, salah satunya pendidikan yang diselenggarakan di sekolah. Melalui pendidikan, seseorang mampu mengembangkan potensi yang dimiliki, sehingga perlu dilakukan berbagai upaya demi peningkatan mutu pendidikan (Kemendikbud, 2014).

Upaya yang dilakukan untuk meningkatkan mutu pendidikan salah satunya yaitu dengan dilakukan perubahan kurikulum. Di Indonesia sudah mengalami beberapa kali pergantian kurikulum, terakhir diberlakukan kurikulum 2013 sebagai acuan pelaksaan pendidikan di sekolah. Meskipun saat ini masih ada sekolah yang menerapkan Kurikulum Tingkat Satuan Pendidikan (KTSP). Kurikulum Tingkat Satuan Pendidikan (KTSP) merupakan kurikulum operasional yang disusun oleh dan dilaksanakan di masing-masing satuan pendidikan (BSNP, 2006).
Keberhasilan proses pembelajaran Ilmu Pengetahuan Alam (IPA) dapat dilihat salah satunya dari hasil belajar. Menurut Nurhidayat (2011), hasil belajar meliputi ranah kognitif, afektif, dan psikomotor. Ketiga ranah tersebut merupakan satu kesatuan yang tidak dapat dipisahkan.

Berdasarkan hasil wawancara dengan guru IPA di sekolah, hasil belajar aspek kognitif siswa kelas VIIIA SMPN 26 Seluma masih kurang. Hal ini karena hanya 10 orang dari 20 siswa yang mencapai kriteria ketuntasan minimal (KKM) sekolah yaitu $\geq 75$. Selain itu, didapat juga informasi dari aktivitas belajar siswa dikelas, bahwa: (a). Siswa kurang mampu membangun pengetahuan sendiri dan lebih suka mendengar ceramah dari guru; (b). Hanya 50 \% siswa saja dikelas yang mampu dan berani mengemukan pendapatnya mengenai materi pembelajaran; dan (c). Kurangnya sarana dan prasarana.

Berdasarkan hal tersebut, maka dilakukan kolaborasi guru IPA dengan peneliti sebagai salah satu usaha untuk meningkatkan hasil belajar. Penelitian ini merupakan penelitian tindakan kelas dengan model discovery learning materi fotosintesis dengan kompetensi dasar (KD) 2.2. Mendeskripsikan proses perolehan nutrisi dan transformasi energi pada tumbuhan hijau, dengan indikator: (1). Melakukan percobaan proses fotosintesis dalam menghasilkan oksigen dan; (2). Menjelaskan faktor-faktor yang mempengaruhi fotosintesis.

Model discovery learning dianggap cocok dengan materi fotosintesis karena sifatnya yang sesuai dengan pendekatan saintifik, seperti kemampuan untuk bertanya, mengobservasi, mengumpulkan informasi, mengolah informasi, dan membuat kesimpulan berdasarkan data atau informasi sehingga dapat menemukan hubungan antar variabel atau 
menguji hipotesis yang diajukan (Sani, 2014).

Tujuan penelitian ini adalah untuk meningkatkan aktivitas dan hasil belajar siswa kelas VIIIA SMPN 26 Seluma pada materi Fotosintesis melalui penerapan model pembelajaran Discovery Learning.

\section{METODE}

Penelitian ini merupakan Penelitian Tindakan Kelas (PTK) dengan metode deskriptif yang dilakukan dalam 2 kali siklus, setiap siklus terdiri tahap perencanaan, pelaksanaan, pengamatan dan refleksi. Penelitian dilaksanakan pada semester genap tahun ajaran 2017/2018 di SMPN 26 Seluma. Peran peneliti dalam penelitian ini adalah sebagai guru biologi yang mengajar siswa pada materi fotosintesis. Guru dibantu oleh 2 orang observer. Subjek penelitian yaitu 20 siswa kelas VIIIA yang terdiri dari 11 siswa lakilaki dan 9 perempuan.

Teknik pengumpulan data dalam penelitian ini adalah observasi dan tes. Instrumen yang digunakan berupa lembar observasi aktivitas guru dan siswa serta lembar tes. Lembar observasi aktivitas guru dan siswa digunakan untuk mengobservasi aktivitas guru dan siswa dalam kegiatan pembelajaran dengan model Discovery Learning. Lembar tes terdiri dari soal-soal pilihan ganda yang digunakan untuk mengukur hasil belajar siswa. Bentuk tes yang di gunakan dalam penelitian ini adalah tes objektif.

Data hasil observasi aktivitas guru dan siswa dianalisis dengan rerata skor dan kategori rerata skor. Kategori rerata skor aktivitas guru dan siswa dapat dilihat pada Tabel 1.
Tabel 1. Kategori skor lembar observasi aktivitas mengajar guru dan aktivitas belajar siswa

\begin{tabular}{cc}
\hline Rentang Skor & Kategori \\
\hline $9-15$ & Kurang \\
$16-22$ & Cukup \\
$23-29$ & Baik \\
\hline
\end{tabular}

Data ketuntasan hasil belajar siswa dihitung dalam persentase ketuntasan klasikal menggunakan rumus:

$\mathrm{q}=\frac{\sum \text { siswa yang tuntas belajar }}{\sum \text { siswa }} \times 100 \%$

(Aqib, 2014 dalam Amyani 2017).

Keterangan:

$\mathrm{q}=$ ketuntasan belajar klasikal

$\sum$ siswa yang tuntas belajar = jumlah siswa yang memperoleh nilai $\geq 75$

$\Sigma$ siswa $=$ jumlah seluruh siswa.

\section{HASIL DAN PEMBAHASAN}

Data hasil observasi aktivitas mengajar guru dan aktivitas belajar siswa dalam kegiatan pembelajaran dengan model discovery learning dapat dilihat pada Tabel 2.

Tabel 2. Data hasil lembar observasi aktivitas guru dan siswa

\begin{tabular}{lcccc}
\hline Aktivitas & \multicolumn{2}{c}{ Siklus I } & \multicolumn{2}{c}{ Siklus II } \\
\cline { 2 - 5 } & Rerata & Kriteria & Rerata & Kriteria \\
\hline Aktivitas & & Baik & 26 & Baik \\
Guru & 24 & Baik & & \\
$\begin{array}{l}\text { Aktivitas } \\
\text { siswa }\end{array}$ & 24 & Baik & 26 & Baik \\
\hline
\end{tabular}

Berdasarkan pembelajaran yang telah dilakukan menggunakan model discovery learning pada siklus I dan siklus II didapatkan data hasil belajar dapat dilihat pada Tabel 3. 
Tabel 3. Hasil belajar siswa pada siklus I dan siklus II

\begin{tabular}{lcll}
\hline Sikuls & Rerata & $\begin{array}{l}\text { Ketuntasan } \\
\text { Hasil Belajar }\end{array}$ & Kriteria \\
\hline I & 69 & $65 \%$ & $\begin{array}{l}\text { Tidak } \\
\text { Tuntas }\end{array}$ \\
II & 75,5 & $85 \%$ & Tuntas \\
\hline
\end{tabular}

Pada aktivitas mengajar guru dan aktivitas belajar siswa pada siklus I dan siklus II sudah tergolong ke dalam Kriteria baik. Pada tahap stimulasi guru memotivasi siswa dengan memberikan gambar dan video, serta menyampaikan tujuan pembelajaran. Sedangkan kegiatan siswa yaitu memperhatikan gambar yang ditampilkan guru dan siswa mencatat tujuan pembelajaran yang disampaikan oleh guru.

Pada aspek memotivasi siswa dengan memberikan gambar dan video, 1 guru memotivasi siswa dengan cara menampilkan gambar dan video tentang proses fotosintesis di siklus I. Namun pada siklus ini, guru belum optimal dalam memotivasi siswa (kriteria cukup). Pada siklus II guru memotivasi siswa dengan cara memberikan video dan gambar tentang faktor-faktor yang mempengaruhi laju fotosintesis. Setelah dilakukan refleksi, kegiatan guru pada siklus II berjalan optimal (kriteria baik). Hal ini dapat dilihat dari kegiatan siswa yang memperhatikan gambar dan video yang ditampilkan guru dan sudah merespon dengan baik yang dapat dilihat dari siswa dapat menjawab pertanyaan dari guru.

Hal ini sejalan dengan pendapat Hamdu dan Agustina (2011), yang menyatakan bahwa salah satu faktor yang mempengaruhi prestasi siswa adalah motivasi. Dengan adanya motivasi, siswa akan belajar lebih keras, ulet, tekun dan memiliki konsentrasi penuh dalam proses pembelajaran. Dorongan motivasi dalam belajar merupakan salah satu hal yang perlu dibangkitkan dalam upaya pembelajaran di sekolah.

Pada aspek menyampaikan tujuan pembelajaran di siklus I guru belum optimal (kriteria cukup). Namun, setelah dilakukan refleksi pada siklus II kegiatan guru berjalan dengan baik dan optimal (kriteria baik). Secara umum kedua observer telah menilai bahwa pada aspek ini aktivitas telah mengalami peningkatan dari siklus I ke siklus II. Aktivitas guru dan siswa yang telah berkategori baik pada tahap stimulus ini, menandakan siswa telah memiliki rasa ingin tahu dan berkeinginan untuk menyelidiki.

Hal ini didukung oleh pendapat Syah (2005), yang mengatakan bahwa tahap stimulasi berfungsi untuk menyediakan kondisi interaksi belajar yang dapat mengembangkan dan membantu siswa dalam mengeksplorasi dan meningkatkan rasa ingin tahu yang tinggi. Rasa ingin tahu inilah nanti yang memotivasi siswa untuk terus mengikuti pembelajaran hingga mendapatkan jawaban yang jelas atas pertanyaan yang telah dibuat bersamasama dari kegiatan percobaan. Hanya saja guru dituntut berusaha lebih keras untuk bisa membuat seluruh siswa antusias dan termotivasi untuk mengikuti proses pembelajaran. Peran guru dalam hal ini adalah memotivasi belajar siswa dan menyadarkan siswa akan tujuan pembelajaran yang harus dicapai, jika siswa sadar akan tujuan pembelajaran yang harus dicapai dan bersedia melibatkan diri, maka siswa akan mencapai fase motivasi (Dimyati \& Mudjiono, 2013).

Pada tahap problem statement (pernyataan/identifikasi masalah), aktivitas mengajar guru pada siklus I dan siklus II sudah termasuk kedalam kriteria baik. Hal ini dibuktikan dengan pemberian pertanyaan untuk proses mengidentifikasi masalah yang telah disampaikan oleh guru terjawab dengan baik oleh siswa. Sebagai 
refleksi disiklus II, guru hanya mempertahankan kegiatan yang telah dilakukan dengan baik. Tahap pernyataan/identifikasi masalah ini adalah tahap yang paling penting untuk dilakukan oleh siswa. Siswa yang belum berpengalaman akan bingung jika disuruh untuk mengidentifikasi masalah walaupun telah dibantu oleh guru. Hal ini didukung oleh pernyataan Nasution (2005) yang mengatakan bahwa permasalahan yang biasanya digunakan adalah masalah yang telah ditemukan sebelumnya, bukan berdasarkan minat individual.

Pada tahap pengumpulan data, kegiatan yang dilakukan guru adalah menjelaskan prosedur percobaan yang ada di LKS, dan membimbing siswa mengumpulkan data hasil percobaan. Pada aspek menjelaskan prosedur percobaan, kegiatan guru pada siklus I dan siklus II sudah optimal (kriteria baik) karena guru sudah menjelaskan prosedur percobaan secara bertahap dengan menjelaskan datadata yang harus dikumpulkan siswa. Begitupun dengan siswa, kegiatan yang dilakukan siswa pada siklus I dan siklus || sudah optimal (kriteria baik) karena siswa mendengarkan penjelasan prosedur kegiatan percobaan yang disampaikan oleh guru dengan mencatat data-data yang harus dikumpulkan.

Hal ini sesuai dengan pendapat Hosnan (2014), yang menyatakan bahwa prosedur eksperimen atau percobaan salah satunya yaitu memberikan penjelasan kepada siswa tentang alat-alat serta bahan-bahan yang akan dipergunakan dalam eksperimen.

Pada aspek membimbing siswa mengumpulkan data hasil percobaan, kegiatan guru pada siklus I dan siklus II sudah optimal (kriteria baik) karena guru membimbing 5 kelompok siswa untuk mengumpulkan data hasil percobaan. Walaupun sudah optimal namun kegiatan siswa pada siklus I masih kurang optimal (kriteria cukup), hal ini dikarenakan hanya 2-3 kelompok siswa saja yang bekerja sama mengumpulkan data hasil percobaan.

Walaupun guru sudah membimbing seluruh kelompok, namun tetap saja masih ada beberapa kelompok yang kesulitan dalam mengumpulkan data sehingga guru kewalahan dalam membimbing kelompok sehingga banyak waktu yang terbuang dalam tahapan ini. Namun setelah dilakukan refleksi pada siklus II, kegiatan siswa telah mendapat kriteria baik, karena seluruh kelompok siswa bekerja sama mengumpulkan data hasil percobaan. Hal ini menandakan bahwa siswa sudah mampu untuk mengumpulkan informasi atau data melalui kegiatan percobaan untuk membuktikan benar atau tidaknya hipotesis.

Hal ini sesuai dengan pendapat Hosnan (2014), yang menyatakan bahwa pada tahap ini berfungsi untuk menjawab pertanyaan atau membuktikan benar atau tidaknya hipotesis, dengan demikian siswa diberi kesempatan untuk mengumpulkan berbagai informasi yang relevan, membaca literatur, mengamati objek, wawancara dengan narasumber, melakukan uji coba sendiri dan sebagainya. Hal ini juga didukung oleh pendapat Dimyati dan Mudjiono (2015) bahwa eksperimen diartikan sebagai keterampilan untuk mengadakan pengujian terhadap ide-ide yang bersumber dari fakta, konsep, dan prinsip ilmu pengetahuan sehingga dapat diperoleh informasi untuk menerima atau menolak ide.

Pada tahap pengolahan data, Kegiatan yang dilakukan guru dan siswa pada siklus I dan siklus II sudah optimal (kriteria baik) karena guru sudah membimbing 5 kelompok siswa untuk mengolah data hasil percobaan yang diperoleh dan siswa sudah bekerja sama mengolah data hasil percobaan yang 
diperoleh dari kegiatan percobaan "proses fotosintesis dalam menghasilkan oksigen" pada siklus I dan kegiatan percobaan "faktor yang mempengaruhi laju fotosintesis" pada siklus II . Kegiatan selanjutnya yaitu membimbing siswa melakukan diskusi dan menjawab pertanyaan yang ada di LKS. Kegiatan yang dilakukan guru dan siswa pada siklus I dan siklus II sudah optimal (kriteria baik) karena guru sudah membimbing 5 kelompok siswa untuk melakukan diskusi dan menjawab pertanyaan yang ada di LKS dan siswa juga sudah melakukan diskusi dan menjawab pertanyaan yang ada di LKS.

Pada tahap pengolahan data dari siklus I ke siklus II, siswa sudah dapat menganalisis data yang didapat sebelumnya dengan baik. Hal ini didukung pernyataan Dimyati dan Mudjiono (2015), yang menyatakan bahwa siswa dapat mengkaji lebih lanjut secara kuantitatif maupun kualitatif sebagai dasar pengujian hipotesis dan penyimpulan. Hal ini juga didukung oleh pernyataan Rusman (2014), bahwa peran siswa secara khusus adalah berpartisipasi dalam pengembangan serta mengevaluasi kemajuan diri sendiri.

Pada tahap verification (pembuktian), kegiatan yang dilakukan guru pada siklus I masih belum optimal (kriteria cukup), hal ini disebabkan karena guru hanya membimbing beberapa kelompok siswa dalam membuktikan benar atau tidaknya hipotesis yang telah dibuat. Sehingga kelompok siswa yang lainnya bingung ketika menghubungkan antara analisis hasil pengolahan data yang didapat dengan jawaban hipotesis yang mereka buat diawal pembelajaran. Sedangkan pada tahap ini hanya 2-3 kelompok siswa saja yang bekerja sama dalam kelompok untuk melakukan verifikasi data. Namun, setelah dilakukan refleksi di siklus II, kegiatan guru telah optimal (kriteria baik), hal ini dikarenakan guru membimbing 5 kelompok siswa untuk melakukan verifikasi data dan juga seluruh kelompok siswa sudah bekerja sama dalam kelompok untuk melakukan verifikasi data untuk membuktikan benar atau tidak hipotesis yang telah dibuat sehingga seluruh kelompok tidak bingung untuk menghubungkan analisis hasil pengolahan data dengan hipotesis yang telah dibuat.

Hal ini sesuai dengan Permendikbud (2014), yaitu pada tahap verifikasi ini, siswa melakukan pemeriksaan secara cermat untuk membuktikan benar atau tidaknya hipotesis yang ditetapkan dengan temuan alternatif, dihubungkan dengan hasil data yang telah diolah. Verifikasi bertujuan bertujuan agar proses belajar akan berjalan dengan baik dan kreatif untuk menemukan suatu konsep, teori, aturan atau pemahaman melalui contohcontoh yang dijumpai dalam kehidupannya.

Pada tahap generalization (menarik kesimpulan), kegiatan yang dilakukan guru dan siswa pada siklus I dan siklus II masih belum optimal (kriteria cukup), karena guru hanya membimbing 3-4 kelompok siswa dalam membimbing menarik kesimpulan untuk dipresentasikan, dan hanya 2-3 kelompok siswa saja yang bekerja sama dalam kelompok untuk menarik kesimpulan untuk dipresentasiakan. Hal ini disebabkan akibat keterbatasan waktu dan penggunaaan waktu yang terlalu lama saat percobaan dan juga diskusi yang dilakukan oleh siswa sehingga tidak semua kelompok dapat mempresentasikan kesimpulan yang didapat. Manajemen waktu pada model discovery learning ini harus sangat diperhatikan karena banyak kegiatan yang dilakukan dengan model ini. Hal ini sesuai dengan pendapat Hosnan (2014) yang menyatakan discovery learning membutuhkan waktu yang lama untuk 
membantu siswa menemukan teori atau pemecahan masalah lainnya.

Selain meningkatkan aktivitas guru dan aktivitas siswa, model discovery learning pada pembelajaran biologi materi fotosintesis juga meningkatkan hasil belajar siswa. Hal ini dapat diketahui dari peningkatan siklus I ke siklus II. Pada siklus I, jumlah siswa yang mencapai ketuntasan belajar klasikal sebanyak 13 orang dan jumlah siswa yang belum tuntas sebanyak 7 orang. Persentase ketuntasan belajar klasikalnya sebesar 65\% (belum tuntas). Sedangkan pada siklus II, hasil belajar siswa mengalami peningkatan dengan jumlah siswa yang tuntas sebanyak 17 orang, dan yang belum tuntas sebanyak 3 orang dengan persentase ketuntasan belajar klasikal sebesar $85 \%$ (tuntas). Berdasarkan ketetapan SMPN 26 Seluma hasil belajar siswa dapat dinyatakan tuntas secara klasikal apabila ketuntasannya mencapai $80 \%$. Peningkatan yang terjadi pada aktivitas guru, aktivitas siswa dan hasil belajar siswa karena adanya pelaksanaan siklus II yang dilakukan dalam rangka memperbaiki proses belajar pada siklus I yang belum tuntas. Hal ini sesuai dengan pendapat Arifin (2012) dalam Amyani (2017) yang menyatakan hasil belajar merupakan hasil dari suatu interaksi tindak belajar dan tindak mengajar. Artinya model yang digunakan dapat meningkatkan hasil belajar, disini siswa dapat menemukan konsep dari apa yang mereka pelajari dengan melakukan pengamatan dan percobaan menggunakan LKS yang diberikan guru.

Hal ini sesuai dengan pernyataan Kemendiknas (2013), yang menyimpulkan bahwa penemuan konsep terjadi bila konsep tidak disajikan dalam bentuk finalnya, tetapi diharapkan dengan model discovery learning siswa mampu mengorganisasi sendiri konsep yang diterimanya.
Penerapan model discovery learning memberikan kesempatan kepada seluruh siswa untuk terlibat secara aktif dalam membangun konsep pelajaran, siswa dapat berfikir kritis untuk menemukan konsep yang belum pernah mereka tahu sebelumnya dan berani menyampaikan hasil temuan mereka dengan menjawab pertanyaan secara tertulis pada lembar kerja siswa dan menyampaikannya di depan kelas. Hal ini sesuai dengan pendapat Putrayasa (2014) yang menyatakan bahwa discovery learning adalah suatu tipe pembelajaran dimana siswa membangun pengetahuan mereka sendiri dengan mengadakan suatu percobaan dan menemukan sebuah prinsip dari hasil percobaan tersebut.

Jadi, dapat disimpulkan bahwa model discovery learning dapat meningkatkan hasil belajar siswa kelas VIIIA SMPN 26 Seluma. Hal ini sejalan dengan penelitian Mulyanti (2015) yang menyatakan bahwa Penerapan Pendekatan Saintifik Dengan Model Discovery Learning Pada Pembelajaran IPA Sistem Transportasi Pada Manusia dapat Meningkatkan Hasil Belajar Siswa Kelas VIIIA SMPN 1 Pondok Kelapa dengan ketuntasan klasikal 63,33\% menjadi $86,66 \%$.

\section{PENUTUP}

\section{Simpulan}

Pembelajaran dengan model discovery learning dalam proses pembelajaran biologi materi fotosintsesis dapat meningkatkan aktivitas guru dan aktivitas siswa kelas VIIIA SMPN 26 Seluma dengan rerata aktivitas guru siklus I 24 (baik) menjadi 26 (baik) pada siklus II dan aktivitas siswa dengan rerata siklus 124 (baik) menjadi 26 ( baik) pada siklus II.

Pembelajaran model discovery learning pada materi fotosintesis ini juga dapat meningkatkan hasil belajar siswa 
kelas VIIIA SMPN 26 Seluma yaitu dengan ketuntasan klasikal pada siklus I 65\% (Tidak Tuntas) menjadi $85 \%$ (Tuntas) pada siklus II.

\section{Saran}

1) Guru mata pelajaran IPA Biologi SMPN 26 Seluma dapat menggunakan model discovery learning sebagai upaya meningkatkan aktivitas dan hasil belajar siswa dengan memperhatikan dan memahami tahapan-tahapan model discovery learning.

2) Peneliti diharapkan lebih dapat memahami tiap tahapan yang terdapat pada model discovery learning, terutama pada tahap data collection dan verification serta dapat memanage waktu dengan baik pembelajaran dapat lebih maksimal.

\section{DAFTAR PUSTAKA}

Amyani, Era siska. 2017. Penerapan Model Discovery Learning pada Pembelajaran IPA Sistem Ekskresi pada Manusia untuk Meningkatkan Aktivitas dan Hasil Belajar Siswa Kelas VIII 2 SMPN 03 Kota Bengkulu. Skripsi tidak diterbitkan. Bengkulu: Program Studi Pendidikan Biologi FKIP Universitas Bengkulu.

Arikunto, S. 2010. Prosedur Penelitian Suatu Pendekatan Praktik. Jakarta : Rineka Cipta.

Badan Standar Nasional Pendidikan (BSNP). 2006. Panduan Penyusunan Kurikulum Tingkat Satuan Pendidikan Jenjang Pendidikan Dasar dan Menengah. Jakarta: BSNP.

Dimyati dan Mudjiono. 2013. Belajar Dan Pembelajaran. Jakarta: Rineka Cipta.

Dimyati dan Mudjiono. 2015. Belajar Dan Pembelajaran. Jakarta: Rineka Cipta.
Hamdu, G. \& Agustina, L. 2011. Pengaruh Motivasi Belajar Siswa Terhadap Pestasi Belajar IPA di Sekolah Dasar. Jurnal Penelitian Pendidikan volume 12 No. 1, (Online), (https://s3.amazonaws.com/ academia. edu.documents/35968572/8Ghullam Hamdu1.pdf, di akses 22 Mei 2018)

Hosnan. 2014. Pendekatan Saintifik dan Kontekstual Dalam Pembelajaran Abad 21. Bogor: Penerbit Ghalia Indonesia.

Kementerian Pendidikan dan Kebudayaan. 2013. Model Pembelajaran Penemuan (Discovery Learning).

Kementerian Pendidikan dan Kebudayaan. 2014. Modul Pelatihan Implementasi Kurikulum 2013. Jakarta: Kementerian Pendidikan dan Kebudayaan.

Kemendiknas. 2013. Materi Pelatihan Guru Implementasi Kurikulum 2013 Smp / Mts Ilmu Pengetahuan Alam. Jakarta : Kemendiknas.

Nasution. 2005. Total Quality Management. Jakarta: PT Gramedia Pustaka Utama

Permendikbud Nomor 58 Tahun 2014 Tentang Kurikulum 2013 Sekolah Menengah Pertama/Madrasah Tsanawiyah. Jakarta: Kementerian Pendidikan Dan Kebudayaan Republik Indonesia (Salinan)

Putra, S. R. 2013. Desain Belajar Mengajar Kreatif Berbasis Sains. Yogyakarta: Diva Press

Putrayasa, I Made., Syahruddin, H., dan Margunayasa, I Gede. 2014. Pengaruh Model Pembelajaran Discovery Learning Dan Minar Belajar Terhadap Hasil Belajar IPA Siswa. Singaraja: Jurnal Mimbar PGSD Universitas Pendidikan Ganesha 
Rusman. $2014 . \quad$ Model-Model

Pembelajaran Mengembangkan

Profesionalisme Sekolah Menengah

Pertama/Madrasah

Tsanawiyah.Jakarta: Kementerian

Pendidikan dan Kebudayaan.

Sani, Ridwan Abdullah. 2014.

Pembelajaran Saintifik Untuk

Implementasi Kurikulum 2013.

Jakarta : Bumi Aksara

Syah, Muhibbin. 2005. Psikologi

Pendidikan dengan Pendekatan

Baru. Bandung: Remaja Rosdakarya 